Provided for non-commercial research and education use. Not for reproduction, distribution or commercial use.

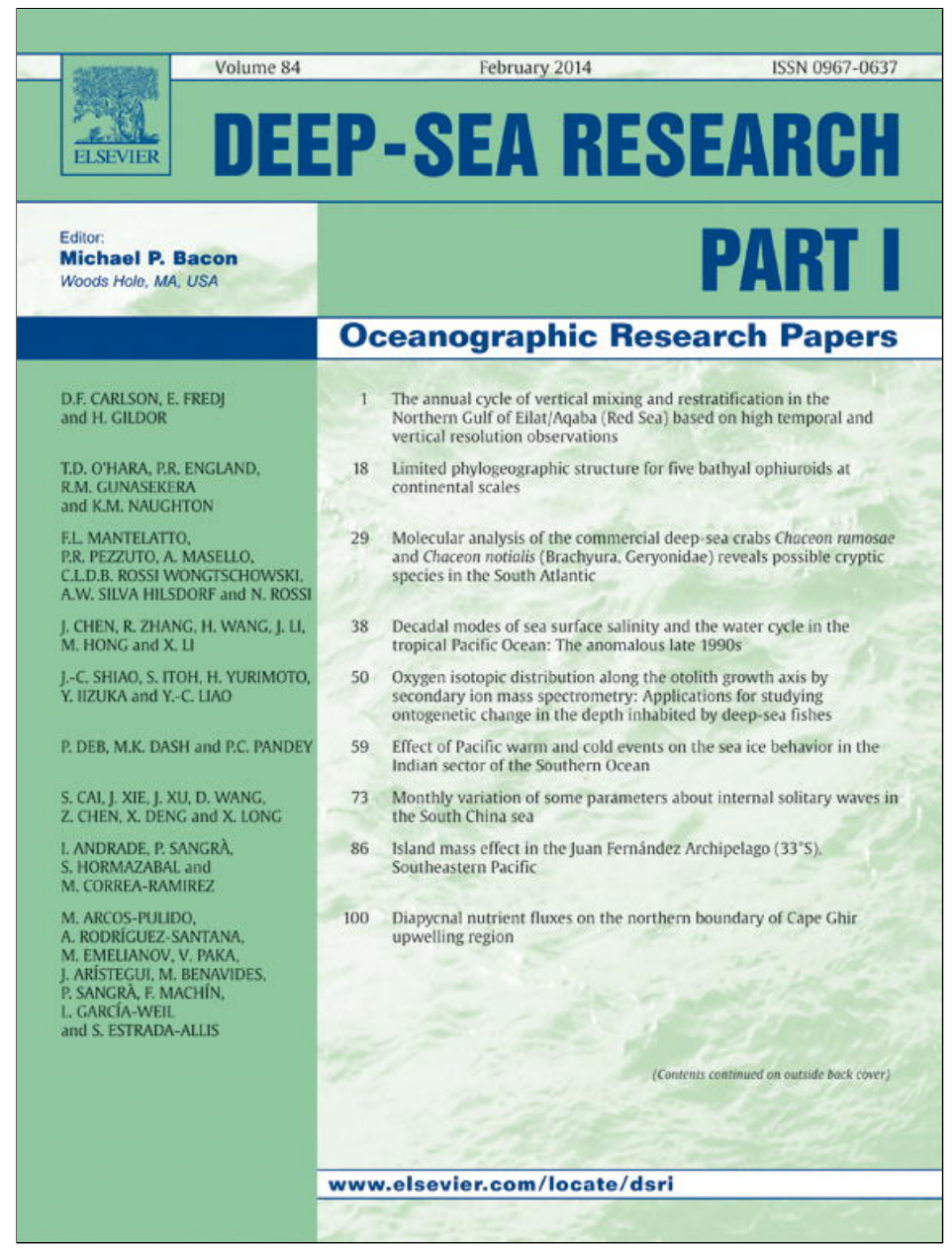

This article appeared in a journal published by Elsevier. The attached copy is furnished to the author for internal non-commercial research and education use, including for instruction at the authors institution and sharing with colleagues.

Other uses, including reproduction and distribution, or selling or licensing copies, or posting to personal, institutional or third party websites are prohibited.

In most cases authors are permitted to post their version of the article (e.g. in Word or Tex form) to their personal website or institutional repository. Authors requiring further information regarding Elsevier's archiving and manuscript policies are encouraged to visit:

http://www.elsevier.com/authorsrights 


\title{
Oxygen isotopic distribution along the otolith growth axis by secondary ion mass spectrometry: Applications for studying ontogenetic change in the depth inhabited by deep-sea fishes
}

\author{
Jen-Chieh Shiao $^{\mathrm{a}, *}$, Shoichi Itoh ${ }^{\mathrm{b}}$, Hisayoshi Yurimoto ${ }^{\mathrm{b}}$, Yoshiyuki Iizuka ${ }^{\mathrm{c}}$, Yun-Chih Liao ${ }^{\mathrm{d}}$ \\ a Institute of Oceanography, National Taiwan University, No. 1, Sec. 4, Roosevelt Rd. Taipei 106, Taiwan, ROC \\ ${ }^{\mathrm{b}}$ Natural History Sciences, Hokkaido University, Sapporo 060-0810, Japan \\ ' Institute of Earth Sciences, Academia Sinica, No. 128, Sec. 2, Academia Road, Nankang, Taipei 115, Taiwan, ROC \\ d Biodiversity Research Center, Academia Sinica, No. 128, Sec. 2, Academia Road, Nankang, Taipei 115, Taiwan, ROC
}

\section{A R T I C L E I N F O}

\section{Article history:}

Received 5 March 2013

Received in revised form

27 September 2013

Accepted 11 October 2013

Available online 31 October 2013

\section{Keywords:}

Otolith

Ion probe

Deep-sea fish

\begin{abstract}
A B S T R A C T
This study using tuna otoliths as working standards established a high lateral resolution and precision analysis to measure $\delta^{18} \mathrm{O}_{\text {otolith }}$ by secondary ion mass spectrometry. This analytical approach of the ion probe was applied to deep-sea fishes to reconstruct the likely depths inhabited by the fishes at different life history stages based on the measured $\delta^{18} \mathrm{O}_{\text {otolith }}$ values as a proxy of water temperature. Dramatic increases up to $5-6 \%$ in $\delta^{18} \mathrm{O}_{\text {otolith}}$, representing a temperature decrease of approximately $20^{\circ} \mathrm{C}$, were detected in a blind cusk eel (Barathronus maculatus) otolith and in the otoliths of Synaphobranchus kaupii during leptocephalus metamorphosis to glass eel, inferred from the drop of otolith $\mathrm{Sr} / \mathrm{Ca}$ ratios and increase of otolith growth increment width. $\delta^{18} \mathrm{O}_{\text {otolith }}$ profiles clearly divided the fish's life history into a planktonic stage in the mixed layer of the ocean and a benthic stage on the deep-sea ocean bottom. The habitat shift signal was recorded within a $150 \mu \mathrm{m}$ width of otolith growth zone, which was too narrow to be clearly detected by mechanical drilling and conventional isotopic ratio mass spectrometry. However,

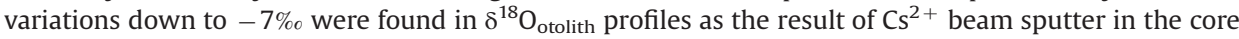
and larval portions of the otoliths. Carbon mapping by electron probe microanalyzer and staining by toluidine blue suggested abundant proteins existed in the areas with anomaly negative $\delta^{18} \mathrm{O}_{\text {otolith }}$ values, which cannot be interpreted as a habitat change but due to the isotopic fractionation by $\mathrm{O}$ emission from the proteins. These results implied that careful design and understanding of the chemical composition of the analytical areas or tracks on the heterogeneous otolith was essential for highly accurate and precise analysis.
\end{abstract}

(c) 2013 Elsevier Ltd. All rights reserved.

\section{Introduction}

Otoliths are calcium carbonate structures in the inner ears of teleostean fish that function as balance and auditory organs (Popper and Coombs, 1982; Cruz et al., 2009). The acellular and metabolically inert otoliths grow continuously throughout the life of a fish and record the environmental characteristics e.g., water temperature experienced by the fish (Campana and Neilson, 1985). Examination of otolith microstructure and chemical compositions has enabled scientists to reveal life history events such as hatching, metamorphosis, settlement, and habitat shifts of the fishes (Hislop et al., 2001; Lin et al., 2012).

$\delta^{18} \mathrm{O}_{\text {otolith }}$ is deposited in equilibrium with ambient water $\delta^{18} \mathrm{O}_{\text {water }}$ and $\delta^{18} \mathrm{O}_{\text {otolith }}$ is influenced by salinity and temperature.

\footnotetext{
* Corresponding author. Tel.: +886 233663227; fax: +886 233663744 .

E-mail address: jcshiao@ntu.edu.tw (J.-C. Shiao).
}

The fractionation factor of $\delta^{18} \mathrm{O}_{\text {otolith }}$ is temperature-dependent (Thorrold et al., 1997) and the negative linear relationship between water temperature and $\delta^{18} \mathrm{O}_{\text {otolith }}$ has been validated for several species (e.g., Høie et al., 2004). $\delta^{18} \mathrm{O}_{\text {otolith }}$ as a proxy of water temperature has wide applications in such diverse fields as migration studies (Northcote et al., 1992), stock discrimination for fishery management (Shiao et al., 2010), and for the reconstruction of paleoclimate (Patterson et al., 1993).

In past decades, mechanical milling and bulk analysis by conventional isotopic ratio mass spectrometer (IRMS) have been the major methodologies used to measure variations in $\delta^{18} \mathrm{O}_{\text {otolith }}$ values throughout the life of the fish (Wurster et al., 1999). Conventional IRMS provides high precise and accurate data, which are able to detect small isotopic variations $(<1 \%$ ) in fish otoliths. However, these methods are limited in temporal resolution due to the need for sample masses of ca. $10-80 \mu \mathrm{g}$, depending on machine types and instrument settings. The requirement for relatively large sample masses means that these methods can track seasonal isotopic 
variations in larger otoliths, but cannot detect isotopic changes at scales of days or weeks.

In contrast, the ion probe technology has greatly advanced in capability in recent decades and is now able to measure isotopic ratios from samples within $\mu \mathrm{m}$-scale spots with a precision and accuracy comparable to conventional IRMS (Hanson et al., 2010). The in situ analysis on small areas $(\sim 10 \mu \mathrm{m})$ by secondary ion mass spectrometry (SIMS) is the only current methodology that can measure isotopic distribution in small otoliths or detect isotopic variations at a daily scale (Weidel et al., 2007). However, the principal challenge for high-precision SIMS analysis is the strong and variable instrumental mass fractionation (IMF) of isotopic compositions that may occur during analysis. Fractionation mediated by sputtering and ionization is one of the complex factors, which may mainly depend on the surface properties of the samples (i.e., chemical composition). This phenomenon is referred to as "matrix effects" or compositionally dependent fractionation (Riciputi et al., 1998). To minimize matrix effects in high precision SIMS analysis, correction by a mineral specific standard is usually essential. Otoliths are not pure minerals; rather, they are biomineralized structures containing minor organic materials e.g., proteins (Degens et al., 1969; Söllner et al., 2003) and various elements intercalated within the calcified daily increments (Campana, 1999). The chemical composition and textures can vary within the same otolith at different life stages. Therefore, correction for IMF with a pure calcium carbonate standard such as NBS19 may not be the best choice.

This study aims to test the feasibility of using tuna otoliths instead of pure $\mathrm{CaCO}_{3}$ as a working standard for $\delta^{18} \mathrm{O}$ analysis by SIMS. Otoliths are impure $\mathrm{CaCO}_{3}$ structure whose organic component may constitute up to $10 \%$ by weight (Sasagawa and Mugiya, 1996; Murayama et al., 2002). The heterogeneity of otolith composition may cause fractionation mediated by matrix effects, and was also investigated. Otoliths of Pacific bluefin tuna (Thunnus orientalis), deep-sea eels (Synaphobranchus kaupii) and blind cusk eels (Barathronus maculatus) were chosen for this work. The

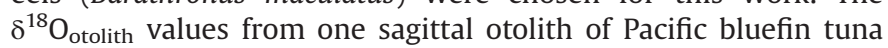
has been determined by mechanical drilling and conventional IRMS in our previous study (Shiao et al., 2010) and the other sagittal otolith from the same individual was used here as the working standard. The blind cusk eel is viviparous, giving birth to live young. Very little is known about the life history of the blind cusk eel. The newly-born larvae of the blind cusk eel were believed to live near the sea bottom after birth (Nielsen et al., 1999). However, this assumption was contradictory to the finding of pelagic larvae of $B$. pacificus in shallower waters (Okiyama and Kato, 1997). We using SIMS technology to clarify the mysterious life history of the blind cusk eel ( $B$. maculatus) by measuring the $\delta^{18} \mathrm{O}_{\text {otolith }}$ profile. The synaphobranchid eels undergo distinct life stages including a planktonic leptocephalus in the warm, shallow oceanic layer (Minagawa et al., 2007) and benthic life on the cold deep-sea floor during juvenile and adult stages (Trenkel and Lorance, 2011). Metamophosis of synaphobranchid eels from leptocephalus to glass eel stage shall be accompanied with decrease of otolith $\mathrm{Sr} / \mathrm{Ca}$ ratios and increase of otolith growth increment widths, which were regarded as the common traits that had been extensively found in many other eel species e.g., anguilid eels, conger eels, moray eels (Otake et al., 1994, Correia et al., 2003; Lin et al., 2005). We hypothesize that $\delta^{18} \mathrm{O}_{\text {otolith }}$ varies as eels transition between habitats of different depths from pelagic larval stage to benthic juvenile and adult. Such kind of ontogenetic habitat shift to the seafloor accompanied with the increase of $\delta^{18} \mathrm{O}_{\text {otolith }}$ values has been found in the deep-sea grenadiers (Lin et al., 2012). However, the leptocephalus stage of synaphobranchid eel may have a slow otolith growth rate similar to that for anguillid eel and conger eel e.g., $<1 \mu \mathrm{m}$ per day (Shiao et al., 2002; Correia et al., 2003) that records transient isotopic variations in narrow otolith growth zones. The signal change within a small growth zone is not easily studied by mechanical drilling and conventional IRMS (Hanson et al., 2010; Lin et al., 2012). The SIMS methodology established in this study provides further insight into the understanding of the mysterious life history of deep-sea fishes and will have wide applications for other species.

\section{Materials and methods}

\subsection{Fish collection}

The Pacific bluefin tuna (T. orientalis, No. PBT3607) is collected in the landing port of Saga, Kochi Prefecture, Japan, which faces the Pacific Ocean on the 17th December 2003. Another Pacific bluefin tuna (No. PBT1910) is collected in the landing port of Hagi, Yamaguchi Prefecture, Japan, which faces the Sea of Japan on the 19th December 2002 (Shiao et al., 2010). A deep-sea blind cusk eel (B. maculatus) and Kaup's cutthroat eels (S. kaupii) are collected from the sea-floor at the depth of $2356 \mathrm{~m}$ for the former and $1242 \mathrm{~m}$ for the later off the east coast of Taiwan by the beam trawl during the cruises of Ocean Researcher I in June 2005 and July 2009, respectively (Table 1). Hydrological data, including salinity and temperature, are measured in situ with a SeaBird CTD (Conductivity-Temperature-Depth) recorder (SBE 9/11 plus, SeaBird Inc., USA).

\subsection{Otolith preparation}

Sagittal otoliths were dissected from the fish after the measurement of total or fork length and weight. One otolith of each tuna was analysed for $\delta^{18} \mathrm{O}$ values by conventional isotope mass spectrometry (Shiao et al., 2010) and the other otolith from the same tuna was prepared for secondary ion mass spectrometry in this study. Tuna otoliths were embedded in epofix resin (Struers, Demark) and a transverse section approximately $400 \mu \mathrm{m}$-thick was cut from the resin block by a slow speed saw (Isomet, Buehler, Evanston, IL, USA) fitted with a diamond-edged blade. The section was embedded in epofix resin again, ground and polished repeatedly on one side with a grinder-polisher machine (Buehler, Metaserv 2000, Evanston, IL, USA) to reveal the incremental pattern. Images of otolith sections were taken by a compound microscope (Olympus BX-51, Japan) equipped with a digital camera (DP-71, Olympus, Japan) using transmitted light.

Otolith powders was collected by a computerized micromill (Merchantek, USA) along several segmented lines that followed the otolith growth zones marked on the real-time computer image from the camera on the top of the micromill. The micromill software interpolated new lines between two adjoining segmented lines according to the desired number of samples. Otolith powder samples, weighing approximately 25-35 $\mu$, were collected from the distal end to the core along the ventral-medial arm. Milled samples were then collected sequentially between each of the lines. Milling depth was set to approximately $200 \mu \mathrm{m}$. After each milling, the otolith image was recorded.

Otoliths of the deep-sea fish were also embedded in epofix resin (Struers, Demark) and the sagittal planes were ground and polished until the core was near the surface. The otolith thin sections of tuna and polished otoliths of deep-sea fish were cast within the central $1.5 \mathrm{~cm}$ of a $2.54 \mathrm{~cm}$ diameter round epoxy (Epxi Cure $^{\circledR}$, Buehler) block. These otoliths were slightly ground and polished by hand using $30 \mu \mathrm{m}, 12 \mu \mathrm{m}, 3 \mu \mathrm{m}$ polishing sheets ( $3 \mathrm{M}$ ) until the cores of the deep-sea fish otolith were exposed on the surface. The samples were finally polished by a vibrating polisher (VibroMet ${ }^{\circledR} 2$ Vibratory Polisher, Buehler) until the surface was 
Table 1

Fish sampled for otolith analysis.

\begin{tabular}{|c|c|c|c|c|c|c|}
\hline Family/species & Code & Weight $(\mathrm{g})$ & Total/fork length $(\mathrm{cm})$ & Date & Depth (m) & Location \\
\hline \multirow[t]{2}{*}{ Scombridae/Thunnus orientalis } & РBT3607 & 2453 & 47.6 & December, 2003 & Sea Surface & Saga, Kochi, Japan \\
\hline & PBT1910 & 939 & 37.5 & December, 2002 & Sea Surface & Hagi, Yamaguchi, Japan \\
\hline \multirow[t]{2}{*}{ Synaphobranchidae /Synaphobranchus kaupii } & Sk3 & 512 & 65.8 & July, 2009 & 1242 & Eastern coast of Taiwan \\
\hline & Sk4 & 331 & 69.2 & July, 2009 & 1242 & $122^{\circ} 13.88^{\prime} \mathrm{E}, 24^{\circ} 22.83^{\prime} \mathrm{N}$ \\
\hline Aphyonidae /Barathronus maculates & BM66390 & 2 & 8.4 & June, 2005 & 2356 & $\begin{array}{l}\text { Eastern coast of Taiwan } \\
122^{\circ} 11.24^{\prime} \mathrm{E}, 24^{\circ} 16.12^{\prime} \mathrm{N}\end{array}$ \\
\hline
\end{tabular}

smooth and flat. The samples were coated with a layer of Au before analysis for $\delta^{18} \mathrm{O}$ by SIMS.

\section{3. $\delta^{18} \mathrm{O}_{\text {otolith }}$ analysis by IRMS}

Oxygen isotope compositions of Pacific Bluefin tuna no. PBT1901 and PBT3607 were analyzed in a Finnigan MAT 253 mass spectrometer (Thermo Electron Corporation, Germany) at National Taiwan University. The $\mathrm{CO}_{2}$ gas for isotope measurements was produced by reaction with pure orthophosphoric acid at $70{ }^{\circ} \mathrm{C}$ in an automated on-line system (Kiel carbonate device IV, Kiel, Germany) with acid added to the sample in individual reaction vials. The long term reproducibility of the Finnigan MAT 253 is better than $\pm 0.08 \%$ ofor $\delta^{18} \mathrm{O}$ (one standard deviation) for an internal carbonate standard $(25-35 \mu \mathrm{g})$.

All isotope values are reported relative to standards by the International Atomic Energy Agency, Vienna. Otolith $\delta^{18} \mathrm{O}$ values are reported in standard $\delta$ notation relative to the Vienna Pee Dee belemnite (VPDB) through calibration against the NBS19 standard:

$\delta^{18} \mathrm{O}=\left(\frac{R_{\text {sample }}-R_{\text {standard }}}{R_{\text {standard }}}\right) \times 1000(\% o)$

where $R$ is the ratio ${ }^{18} \mathrm{O}:{ }^{16} \mathrm{O}$ in the sample or standard.

\section{4. $\delta^{18} \mathrm{O}_{\text {otolith }}$ analysis by SIMS}

The Hokudai isotope microscope system (Cameca ims 1270 SIMS instrument and SCAPS ion imager at Hokkaido University) was applied to determine oxygen isotopic composition of otoliths.

$\mathrm{A} \mathrm{Cs}^{+}$primary beam of $20 \mathrm{keV}$ was focused to an oval spot of $8 \times 10 \mu \mathrm{m}$ on the surface of the sample with a beam current of $\sim 1.4 \mathrm{nA}$. A normal incident electron gun was used to compensate for positive charging of the sputtered region due to the primary beam.

Samples were embedded in epoxy disk of $2.54 \mathrm{~cm}$. in diameter. The disk surface was polished as mirror finished surface and gold-coated of $60 \mathrm{~nm}$ in thickness in order to support the charge compensation by the electron gun.

Negative secondary ions of ${ }^{16} \mathrm{O}^{-}$and ${ }^{18} \mathrm{O}^{-}$were collected simultaneously in a Faraday cup, respectively, using a multiple collection system. Mass resolutions of M/DM were about 2000 for ${ }^{16} \mathrm{O}^{-}$and ${ }^{18} \mathrm{O}^{-}$for $10 \%$ peak height. Typical ion intensities were $\sim 2 \mathrm{Gcps}$ (counts per second) for ${ }^{16} \mathrm{O}^{-}$and $\sim 4.0 \mathrm{Mcps}$ for ${ }^{18} \mathrm{O}^{-}$. Any crack or surface defects were avoided for the spot analysis. The accumulation time was $30 \mathrm{~s}$. per one cycle and the accumulation for one measurement spot (one Run) was repeated for 4 cycles after a pre-sputtering of $390 \mathrm{~s}$. The internal error of each measurement was calculated from the raw data of each 4 cycles, considering the error propagation of instrumental mass fractionation (IMF).

Otolith isotope measurements were bracketed by $5-10$ spots for analyses of an internal working standard, the transverse sectioned tuna otolith (РBT3607), to assess instrument precision. A beam size of $10 \mu \mathrm{m}$ was used for $\delta^{18} \mathrm{O}$ measurements, with a step size of about $30-50 \mu \mathrm{m}$. These values were chosen as conservative parameters for preliminary analyses. The sampling transect originated at the core of the otolith and terminated at the otolith edge.
The precision of this method ranged from $0.11 \%$ o to $0.56 \%$ o (one standard deviation, 1SD) based on the repeated measurements $(n=4$ to 17$)$ on 8 different parts of 2 tuna otoliths used as the working standards.

\subsection{Elemental analysis by EPMA (electron probe microanalyzer)}

Otolith $\mathrm{Sr} / \mathrm{Ca}$ ratios are useful to determine the ontogenetic development from pelagic leptocephalus to benthic glass eel stages for Kaup's cutthroat eels (S. kaupii). Otolith C concentration may provide information about the distribution of organic matter in the otolith for both Kaup's cutthroat eels and blind cusk eel. After $\delta^{18} \mathrm{O}_{\text {otolith }}$ analysis by the ion probe (Camera ims 1270), the otoliths were polished to remove the gold layer then the samples were coated by a layer of carbon (Q150T E, Quorum Technologies Ltd., UK) to facilitate electron conductance. Quantitative and mapping analyses were performed by a JEOL electron microprobe (W-EPMA: JXA-8900R) and a JEOL field emission electron microprobe (FEEPMA: JXA-8500F), respectively, equipped with wavelength dispersive spectrometers at the Institute of Earth Sciences, Academia Sinica, Taipei, Taiwan. Secondary and backscattered electron images were used to guide the analysis on target positions of the otolith. Quantitative analysis was conducted along an axis from the primordium (core) to the edge at $10 \mu \mathrm{m}$ intervals. Primary electron beam conditions were $15 \mathrm{kV}$ for the acceleration voltage and $3 \mathrm{nA}$ for the current, and a $5 \times 4 \mu \mathrm{m}$ rectangular scanning beam size. The wavelength dispersive spectrum at $\mathrm{Sr} \mathrm{L}_{\alpha}$ peak position was measured for $80 \mathrm{~s}$ and each of the upper and lower baselines for $20 \mathrm{~s}$. The peak concentrations of $\mathrm{Ca} K_{\alpha}$ and $\mathrm{C} K_{\alpha}$ were measured for $20 \mathrm{~s}$ and $30 \mathrm{~s}$, respectively, and each of the upper and lower baselines for $10 \mathrm{~s}$. Synthesized aragonite $\left(\mathrm{CaCO}_{3}\right)$ and strontianite $\left[\left(\mathrm{Sr}_{0.95} \mathrm{Ca}_{0.05}\right)\right.$ $\mathrm{CO}_{3}$; NMNH R10065] were used as standards to calibrate the concentrations of $\mathrm{Sr}$ and $\mathrm{Ca}$ in the otoliths. The weight ratio of $\mathrm{Sr} /$ Ca ratio was calculated after correction using the PRZ (phi-rho-z) method (Goldstein et al., 1984; Reed, 1993). Analytical errors were smaller than $0.05 \mathrm{wt} \%$ in Sr (Iizuka, 2012). Chemical distribution (mapping) analysis of $\mathrm{Sr} \mathrm{L}_{\alpha}$ and $\mathrm{C} K_{\alpha}$ was performed by a field emission EPMA (JXA-8500F) at conditions of $15 \mathrm{kV}$ and $85 \mathrm{nA}$ for the acceleration voltage and beam current, respectively, with a focused beam. The X-ray intensity of each element was counted for $0.04 \mathrm{~s}$ at an interval of $1 \mu \mathrm{m}$ with the $X-Y$ stage driving.

\subsection{Staining of otoliths and age determination}

After microchemical analysis by EPMA, the otoliths were polished to remove the carbon coating. The otolith surface was then immersed in the 1\% toluidine blue solution (prepared from $1 \%$ boric acid, $\mathrm{pH}>10$ ) for 15 min to stain the proteins (Mercer, 1963). Distilled water was used to remove the remaining toluidine blue solution, before the otoliths were observed under a light microscope. Otoliths were etched with 5\% EDTA (ethylenediaminetetraacetate, $\mathrm{pH}=4.5$ ) for $20 \mathrm{~s}$ to reveal the daily growth increments and annuli for age determination using secondary electron micrographs by a scanning electron microscope (JEOL JSM-6360LV, Japan) with a gold coating of the otoliths. 


\subsection{Predicted $\delta^{18} \mathrm{O}_{\text {otolith }}$ by salinity and water temperature}

The $\delta^{18} \mathrm{O}_{\text {otolith }}$ fractionation specific to deep-sea fish is still unknown although the relationship between water temperature

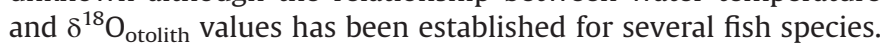
We used the CTD data i.e., water temperature and salinity to predict $\delta^{18} \mathrm{O}_{\text {otolith }}$ values from the sea surface to $2200 \mathrm{~m}$ depth based on the equations developed by Thorrold et al. (1997) and Kim and O'Neil (1997), which predicted the highest and lowest $\delta^{18} \mathrm{O}_{\text {otolith }}$ values, respectively among the published data reporting the relationship between temperature and $\delta^{18} \mathrm{O}_{\text {otolith }}$. The inorganic calcite equation developed by Kim and O'Neil (1997) was modified to reflect aragonite (otolith) which is enriched in ${ }^{18} \mathrm{O}$ by $0.6 \%$ relative to calcite during precipitation at $25{ }^{\circ} \mathrm{C}$ (Tarutani et al., 1969).

$\delta^{18} \mathrm{O}_{\text {otolith }}-\delta^{18} \mathrm{O}_{\text {water }}=3.71-0.206 T\left({ }^{\circ} \mathrm{C}\right)$

In this equation, $\delta^{18} \mathrm{O}_{\text {otolith }}$ is the otolith $\delta^{18} \mathrm{O}$ value (in the VPDB scale), $\delta^{18} \mathrm{O}_{\text {water }}$ is the water $\delta^{18} \mathrm{O}$ value in the VSMOW (Vienna Standard Mean Ocean Water) scale of ambient water and $T$ is the water temperature. $\delta^{18} \mathrm{O}_{\text {water }}$ can be described by the equation for salinity near Ishigaki Island, southwestern Japan (Abe et al., 2009): $\delta^{18} \mathrm{O}_{\text {water }}=-10.3+0.31 \times$ salinity. $\quad \delta^{18} \mathrm{O}_{\text {water }}$ is reported in the VSMOW scale that can be converted to the VPDB scale by the equation (Friedman and O'Neil, 1977): $\delta^{18} \mathrm{O}_{\text {water }}(\mathrm{VPDB})=$ $0.99978 \times \delta^{18} \mathrm{O}_{\text {water }}(\mathrm{VSMOW})-0.22$.

\section{Results}

\subsection{Tuna $\delta^{18} O_{\text {otolith }}$ values analyzed by IRMS and SIMS}

Tuna $\delta^{18} \mathrm{O}_{\text {otolith }}$ values measured by IRMS have been reported previously (Shiao et al., 2010) and the isotopic profiles were described here in detail. Tuna (PBT1910) $\delta^{18} \mathrm{O}_{\text {otolith values mea- }}$ sured by IRMS were depleted at $-2.36 \%$ o to $-2.29 \%$ o between the core and $884 \mu \mathrm{m}$ then the values dramatically increased to approximately $-1.20 \%$ at the otolith edge before the winter (Fig. 1). Tuna (PBT3607) $\delta^{18} \mathrm{O}_{\text {otolith }}$ values were $-2.18 \%$ o before $546 \mu \mathrm{m}$ from the core then the values rose from $-2.75 \%$ at $600-$ $700 \mu \mathrm{m}$ to $-1.91 \%$ at the otolith edge. The initial subsample drilled from the otolith core of PBT3607 was only ca. $15 \mu \mathrm{g}$, which fell below minimum requirements (approximately 25-30 $\mu \mathrm{g}$ ) for IRMS analysis (Shiao et al., 2010). Therefore, the high measured value $(-2.18 \%$ ) was attributed to isotopic fractionation of insufficient mass. Sagittal otoliths from the other side of these two tuna were assumed to have the same $\delta^{18} \mathrm{O}_{\text {otolith }}$ profiles, which were measured by SIMS (Cameca ims 1270). The repeated analyses by 10 spots on the different parts of the same increments were conducted at approximately $750 \mu \mathrm{m}$ and $1150 \mu \mathrm{m}$ from the core of the otolith in PBT1910 (Fig. 1). CCD images of the SIMS and otolith photos taken during sample preparation showed primary ion beam sputtering on the same growth increments. The differences in $\delta^{18} \mathrm{O}_{\text {otolith }}$ values between these 2 zones were $1.20 \%$ by SIMS analysis, and $1.14 \%$ ob IRMS analysis (Fig. 1 ), which was essentially within the same analytical errors. Another two repeated analyses (10 and 7 spots) were conducted at approximately $600 \mu \mathrm{m}$ from the otolith core and at the otolith edge of PBT3607, respectively.

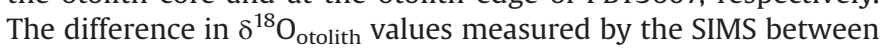
these 2 zones was $0.73 \%$, which was also close to the difference derived by IRMS between the corresponding zones (0.84\%o, Fig. 1). The consistent results measured by IRMS and SIMS suggested that tuna otolith can be used as working standards for the analysis of $\delta^{18} \mathrm{O}_{\text {otolith }}$ values by the ion probe (ims 1270).
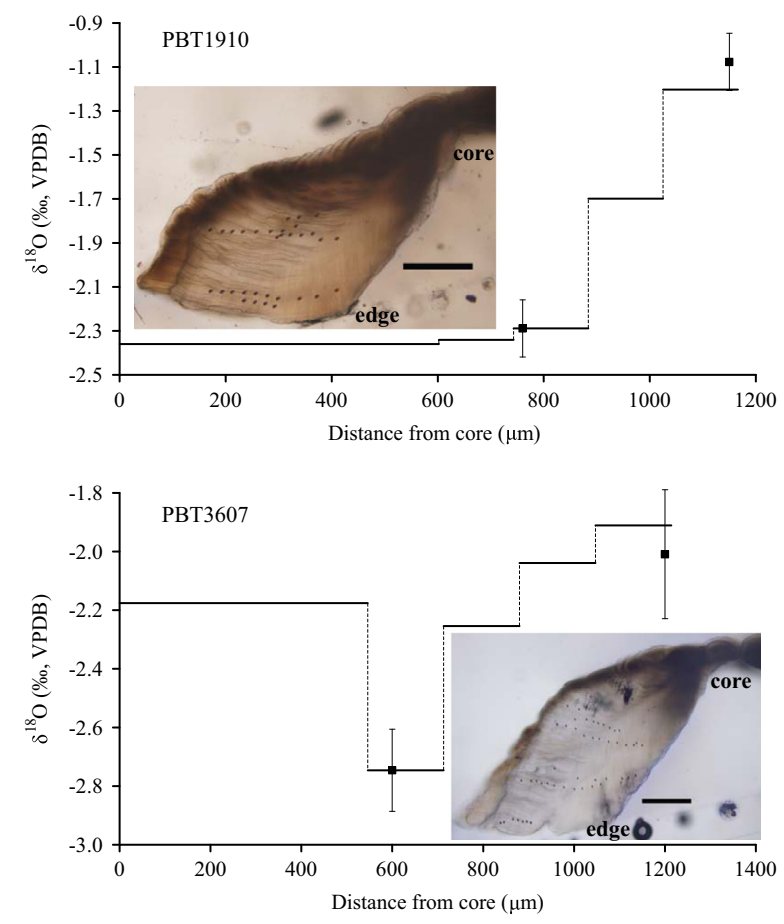

Fig. 1. Pacific bluefin tuna (Thunnus orientalis). Each side of the sagittal otolith of the same tuna was measured for the $\delta^{18} \mathrm{O}_{\text {otolith }}$ values by the isotope ratio mass spectrometry (IRMS) and the secondary ion mass spectrometry (SIMS), respectively. The line profiles showed the temporal variations of the $\delta^{18} \mathrm{O}_{\text {otolith }}$ from the otolith core to the edge that were separately collected by mechanical drilling and analyzed by the IRMS. The other sagittal otolith as shown in the image was analyzed by the SIMS and only two repeated measured data on the same growth increments was shown as mean values $( \pm 1 \sigma)$ in the vertical bar at the two corresponding positions. The small black spots were the locations bombarded by

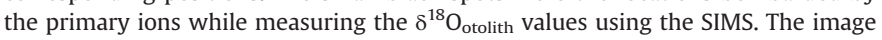
scale bar is $200 \mu \mathrm{m}$.

\section{2. $\delta^{18} \mathrm{O}_{\text {otolith }}$ analyzed by SIMS}

Before conducting analysis on the otoliths of Kaup's cutthroat eels and a blind cusk eel, the machine (ims 1270) condition was evaluated by analyzing 17 spots on two different incremental zones of tuna PBT3607, whose otolith was cast in the same epoxy disk. The measured $\delta^{18} \mathrm{O}_{\text {otolith }}$ of these 17 spots have been described above in Fig. 1 and the spot-to-spot reproducibility was $0.51 \%$ (1SD, $n=10$ ) and $0.29 \%$ (1SD, $n=7$ ). All these samples including the tuna PBT3607, two Kaup's cutthroat eels and a blind cusk eel were continuously analyzed over $22 \mathrm{~h}$ with the same analytical parameters. Therefore, the measured data of PBT3607 were used to calculate the instrumental mass fractionation between IRMS and SIMS methods.

Approximately 5-10 spot analyses on two Kaup's cutthroat eels and a blind cusk eel were bracketed by the analysis on the working standard of the tuna (PBT3607) otolith at approximately $900 \mu \mathrm{m}$ from the core. The spot-to-spot reproducibility of the analysis on the same growth increments of the working standard was $0.45 \%$ o (1SD, $n=17$ ) during the analytical period for the otoliths of the two Kaup's cutthroat eels and a blind cusk eel.

The $\delta^{18} \mathrm{O}_{\text {otolith }}$ profiles of the blind cusk eel (BM66390) varied from $0.09 \%$ at the core to $-4.33 \%$ at $642 \mu \mathrm{m}$ from the core. Then, the values dramatically increased to a peak of 4.67-6.62\%o from $831 \mu \mathrm{m}$ to the otolith edge (Fig. 2). The internal errors were unexpectedly large (approximately 1\%, 2 standard error of the mean) for the dots 4-10 (241-642 $\mu \mathrm{m}$ from the core). An otolith check appeared immediately after the $\delta^{18} \mathrm{O}_{\text {otolith }}$ values reached a plateau, which separated the microstructure into inner-darker and outer-lighter areas (Fig. 2) as observed by reflected light under a 
compound light microscope. No daily rings or annuli were observed although approximately 11 rings were identified near the core during the preparation for SIMS analysis (Fig. 2). However, this core area was lost due to over polishing. It was therefore not possible to estimate the temporal resolution of each spot measurement.

Kaup's cutthroat eels also showed 3 -phase $\delta^{18} \mathrm{O}_{\text {otolith }}$ profiles with negative values before $100-150 \mu \mathrm{m}$ from the core, then an abrupt increase to high levels between $4.61 \%$ ond $6.03 \%$ o for eel Sk3 and $1.55 \%$ o $-4.58 \%$ o for eel Sk4. The $\delta^{18} \mathrm{O}_{\text {otolith }}$ values at the edges of eel Sk3 (4.78\%o) and Sk4 (4.46\%) were very close (Fig. 3), in good agreement with the catch of the eels at the same location and depth. The otolith core of eel Sk3 was lost due to over polishing; therefore the first spot represented the early larval stage rather than the true core. The first spot on the true core of eel Sk4 showed a very negative value of $-6.76 \%$. Observations by SEM could identify only 145 and 140 growth increments within the inner region of the otolith corresponding to the larval stage for eels Sk3 and Sk4, respectively. Since the core was lost in the eel Sk3, ring counts underestimated the number of rings actually deposited. The growth increment width was narrow (approximately $0.4-0.8 \mu \mathrm{m}$ ) from the otolith core to around 100 increments and the increment width increased to approximately $2.2 \mu \mathrm{m}$ between 141 and 145 increments for eel Sk3 and 135-140 increments for eel Sk4. Thirteen and eleven major rings, assumed to be annuli, were identified in the otoliths of eels Sk3 and Sk4, respectively. Each $\delta^{18} \mathrm{O}_{\text {otolith }}$ value was measured on an oval spot of $8 \times 10 \mu \mathrm{m}$ but each spot may cover different time scale among

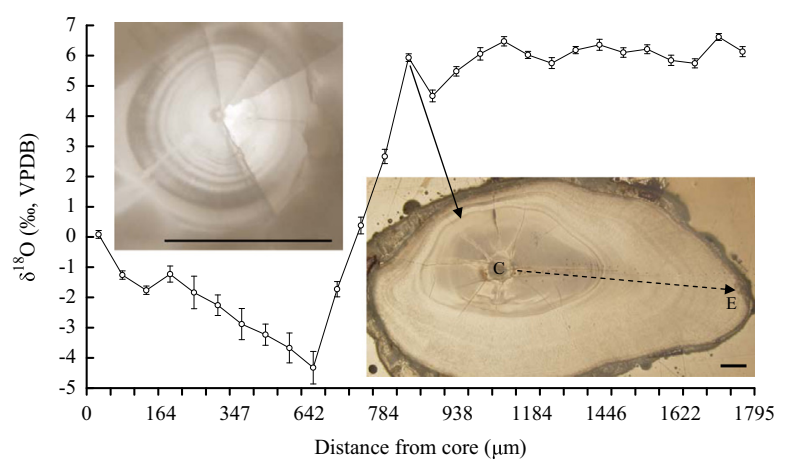

Fig. 2. Temporal variations in the $\delta^{18} \mathrm{O}_{\text {otolith }}$ profile from the otolith core $(\mathrm{C})$ to the edge (E) for blind cusk eel (Barathronus maculatus) along the transect indicated by the dashed arrow. The solid arrow indicates the position of the otolith check that corresponds to the highest $\delta^{18} \mathrm{O}_{\text {otolith }}$ value during the increase from negative values. The otolith growth increments near the core are shown in upper left image. The image scale bar is $200 \mu \mathrm{m}$.

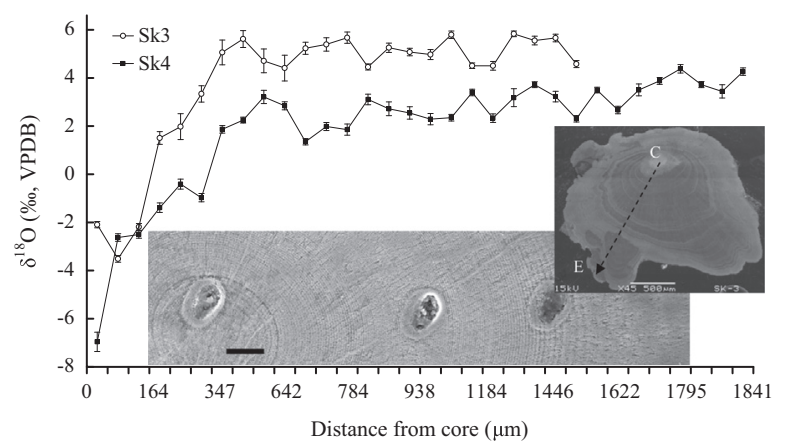

Fig. 3. Temporal variations in the $\delta^{18} \mathrm{O}_{\text {otolith }}$ profiles from the otolith core $(\mathrm{C})$ to the edge (E) for Kaup's cutthroat eels (Synaphobranchus kaupii) along the transect indicated by the dashed arrow on the image for the eel Sk3. The likely daily growth increments and the first 3 spots from the core to metamorphosis zone of the Sk3 eel are shown in the SEM image. The scale is $10 \mu \mathrm{m}$. different life stages; approximately 15 growth increments in the leptocephalus stage, 5 increments during the metamorphosis to glass eel as shown in Fig. 3, and possibly 1-2 months during benthic life on the deep-sea floor estimated from the spot size and the annulus width between annuli 1-11 (Sk4) and 1-13 (Sk3).

\subsection{Water temperature, salinity and predicted $\delta^{18} \mathrm{O}_{\text {otolith }}$}

CTD profile was measured near the locations where the Kaup's cutthroat eels and the blind cusk eel were caught off eastern coast of Taiwan $\left(122.032^{\circ} \mathrm{E}, 23.954^{\circ} \mathrm{N}\right)$. Within the mixed layer $(<40 \mathrm{~m}$ depth), seawater temperature was stable at $26-27^{\circ} \mathrm{C}$, followed by the decrease from $25{ }^{\circ} \mathrm{C}$ to $4{ }^{\circ} \mathrm{C}$ in the thermocline $(40-800 \mathrm{~m}$ depth) according to the CTD data. In the deep sea between 800 and $2200 \mathrm{~m}$ depth, the water temperature was almost stable with a slow decrease from $4{ }^{\circ} \mathrm{C}$ to $1{ }^{\circ} \mathrm{C}$. Salinity gradually increased from 34.4 to 34.8 in the mixed layer then decreased to 33.3 near the lower boundary of the thermocline. Below $800 \mathrm{~m}$ depth, the salinity slowly increase to 34.6 (Fig. 4).

The predicted $\delta^{18} \mathrm{O}_{\text {otolith }}$ values increased from $-1 \%$ or $-2 \%$ o at the sea surface to $5 \%$ or $3 \%$ at $2200 \mathrm{~m}$ depth based on the equations of Thorrold et al. (1997) and Kim and O'Neil (1997), respectively (Fig. 5). Although the predicted values varied between equations, trends were consistent across profiles. The predicted $\delta^{18} \mathrm{O}_{\text {otolith }}$ values were stable in the ocean surface $(<40 \mathrm{~m})$ then quickly increased $1 \%$ with depth down to $60 \mathrm{~m}$, then the values gradually increased to a plateau around $1000 \mathrm{~m}$ depth.

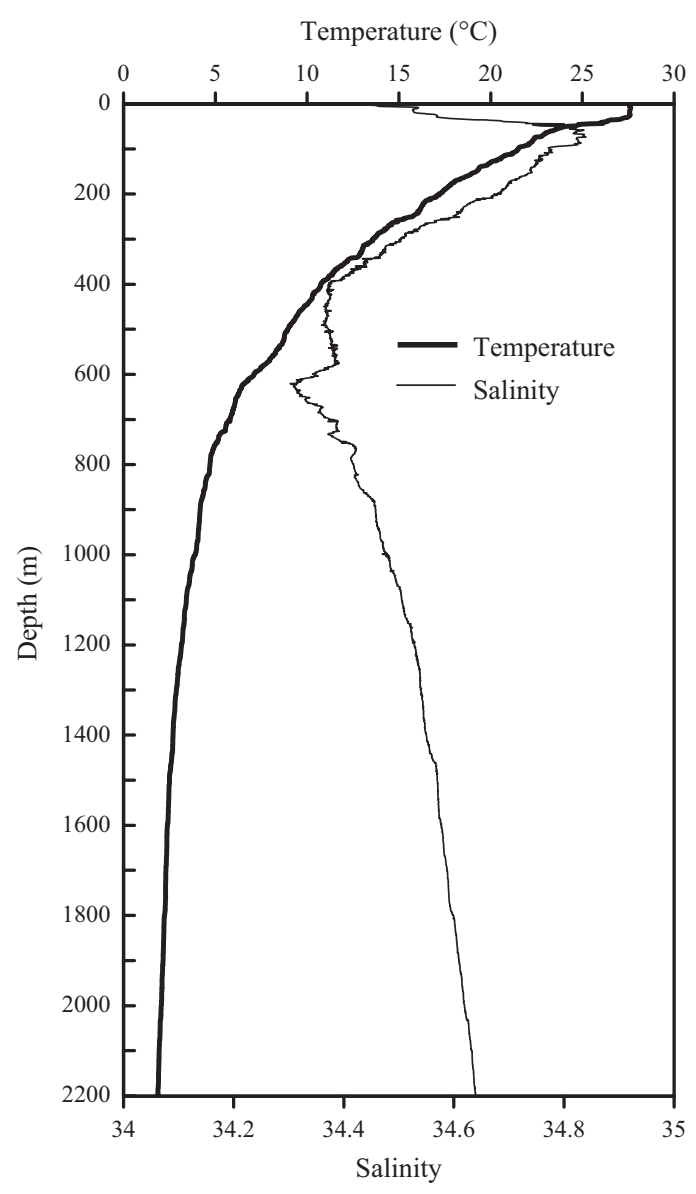

Fig. 4. Temperature and salinity profiles from the ocean surface to $2200 \mathrm{~m}$ depth at the sampling location for deep-sea fishes off eastern Taiwan on the 7th November 2011. 


\subsection{Elemental analysis and otolith microstructure}

Otolith $\mathrm{Sr} / \mathrm{Ca}$ ratios of Kaup's cutthroat eels increased from approximately $7 \times 10^{-3}$ in the core to a peak of $11.3 \times 10^{-3}(\mathrm{Sk} 3)$ and $17.2 \times 10^{-3}(\mathrm{Sk} 4)$ around $30-40 \mu \mathrm{m}$ from the core. Then the values sharply decreased to a level similar to the values near the core (Fig. 6). The decrease in $\mathrm{Sr} / \mathrm{Ca}$ ratios coincided with the increase in growth increments from $0.4 \mu \mathrm{m}$ to $2.2 \mu \mathrm{m}$ (Fig. 3), which indicated the metamorphosis of the eels from the leptocephalus to the glass eel stage (Correia et al., 2003). Carbon was homogeneously distributed in most areas of the eels Sk3 and Sk4 otoliths except for the higher $C$ concentrated around and within the core (Fig. 7). However, heterogeneous distributions of $C$ were found in the otolith of the blind cusk eel (BM66390). The staining by toluidine blue solution created few blue areas and most areas

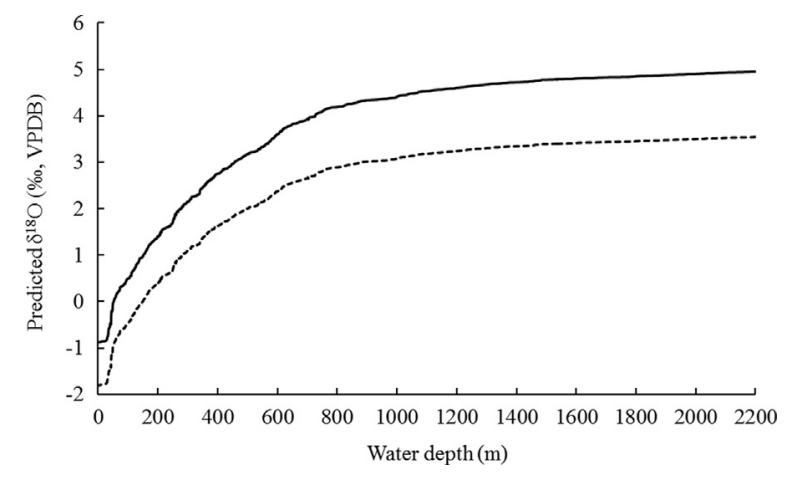

Fig. 5. Predicted $\delta^{18} \mathrm{O}_{\text {otolith }}$ profiles estimated from water temperature and salinity at measured from the sea surface to $2200 \mathrm{~m}$ depth at the sampling location off eastern Taiwan. Solid and dashed lines represent predicted values derived from the equations of Thorrold et al. (1997) and Kim and O'Neil (1997), respectively.
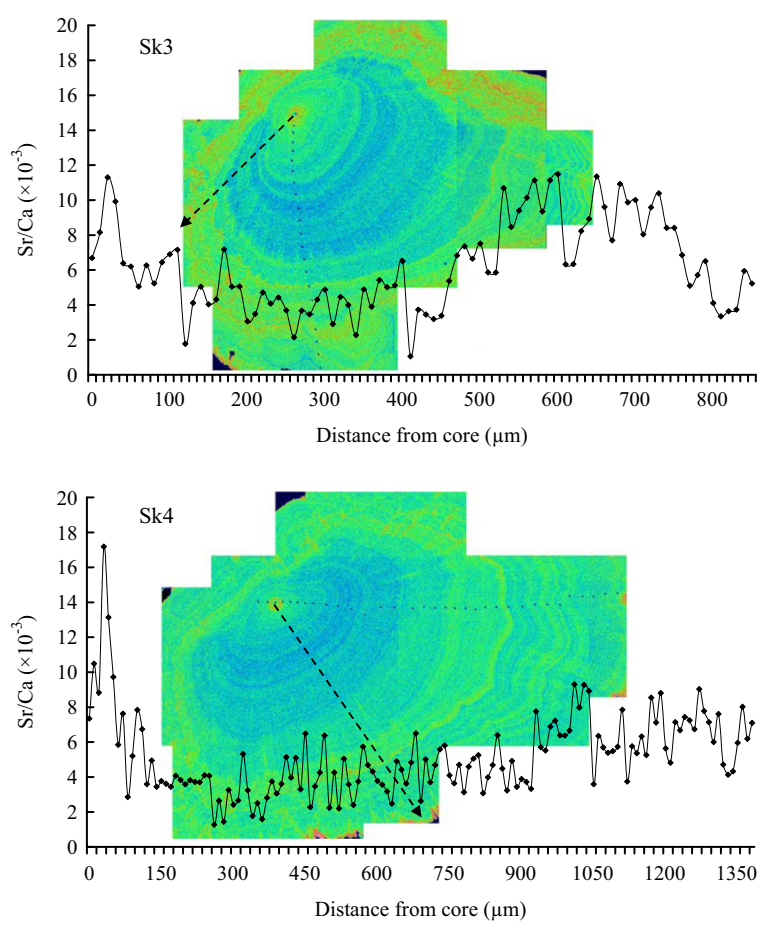

Fig. 6. Strontium (Sr) mapping and $\mathrm{Sr} / \mathrm{Ca}$ ratios from otolith core to the edge for Kaup's cutthroat eels (S. kaupii) along the transect indicated by the dashed arrows. High Sr rings and the $\mathrm{Sr} / \mathrm{Ca}$ peaks ( $<40 \mu \mathrm{m}$ from the core) of Sk3 and Sk4 represent the commencement of metamorphosis from the leptocephalus to the glass eel stage. The small spots were the locations bombarded by the primary ions while measuring the $\delta^{18} \mathrm{O}_{\text {otolith }}$ values using the SIMS.

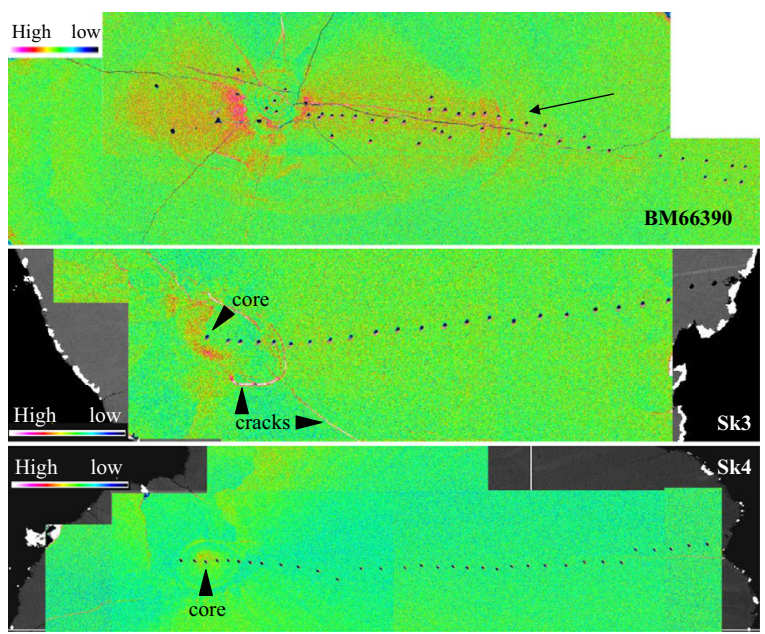

Fig. 7. Otolith carbon mapping for the blind cusk eel (B. maculatus, code: BM66390) and Kaup's cutthroat eels (S. kaupii) (Sk3, Sk4). Red color indicates areas of high carbon concentrations distributed between the core and the otolith check (indicated by the arrow) of the blind cusk eel and near the core of Kaup's cutthroat eels. Carbon mapping is superimposed on the backscattered images for the eels Sk3 and Sk4. The spots were the locations bombarded by the primary ions while measuring the $\delta^{18} \mathrm{O}_{\text {otolith }}$ values using the SIMS. (For interpretation of the references to color in this figure legend, the reader is referred to the web version of this article.)

remained clear and colorless (Fig. 8). For the blind cusk eel, the otolith surface with higher $\mathrm{C}$ concentrations (Fig. 7) was almost identical with the blue stained areas (Fig. 8). The blue staining also appeared in the larval stage of the cutthroat eel (Sk4) otolith but the staining intensity was weaker than that in the blind cusk eel. The blue staining color was weaker in the larval stage of eel Sk3 than that in Sk4.

\section{Discussion}

\subsection{Advantages of using otoliths as working standards}

Using fish otoliths as working standards for $\delta^{18} \mathrm{O}_{\text {otolith }}$ analysis by SIMS has several theoretical advantages. Matrix effects can be reduced to minimal levels since the standards and unknown samples are all fish otoliths with similar compositions. Furthermore, otoliths used as the working standard furnish different isotopic values at each life stage, which is useful to evaluate the reproducibility of the analysis as well as to monitor instrumental conditions. The homogeneity of a standard is a critical concern for ion probe analysis. Isotopic heterogeneity of National Institute of Standards (NIST) NBS18, NBS19 and other carbonate standards have been reported by SIMS analysis (Kolodny et al., 2003; Treble et al., 2005, 2007). On the other hand, otolith growth increments are deposited at the same time with the same chemical compositions, which provide isotopically homogeneous standard for repeated measurement on the same growth increments of a given otolith. It is easy to acquire fish otoliths for use as standards that can be cast in the same epoxy resin with the unknown samples. Nevertheless, this study also found potential problems when analyzing heterogeneous otoliths as standards or unknown samples.

\subsection{Concerns of measuring $\delta^{18} \mathrm{O}_{\text {otolith }}$ by SIMS}

A large fractionation down to $-7 \%$ of $\delta^{18} \mathrm{O}_{\text {otolith }}$ was found during the process of primary ion sputtered on the otolith core of Kaup's cutthroat eels $(S k 4)$. The anomaly negative values of $\delta^{18} \mathrm{O}_{\text {otolith }}(-2 \%$ o to $-5 \%$ ) with larger internal errors were also 


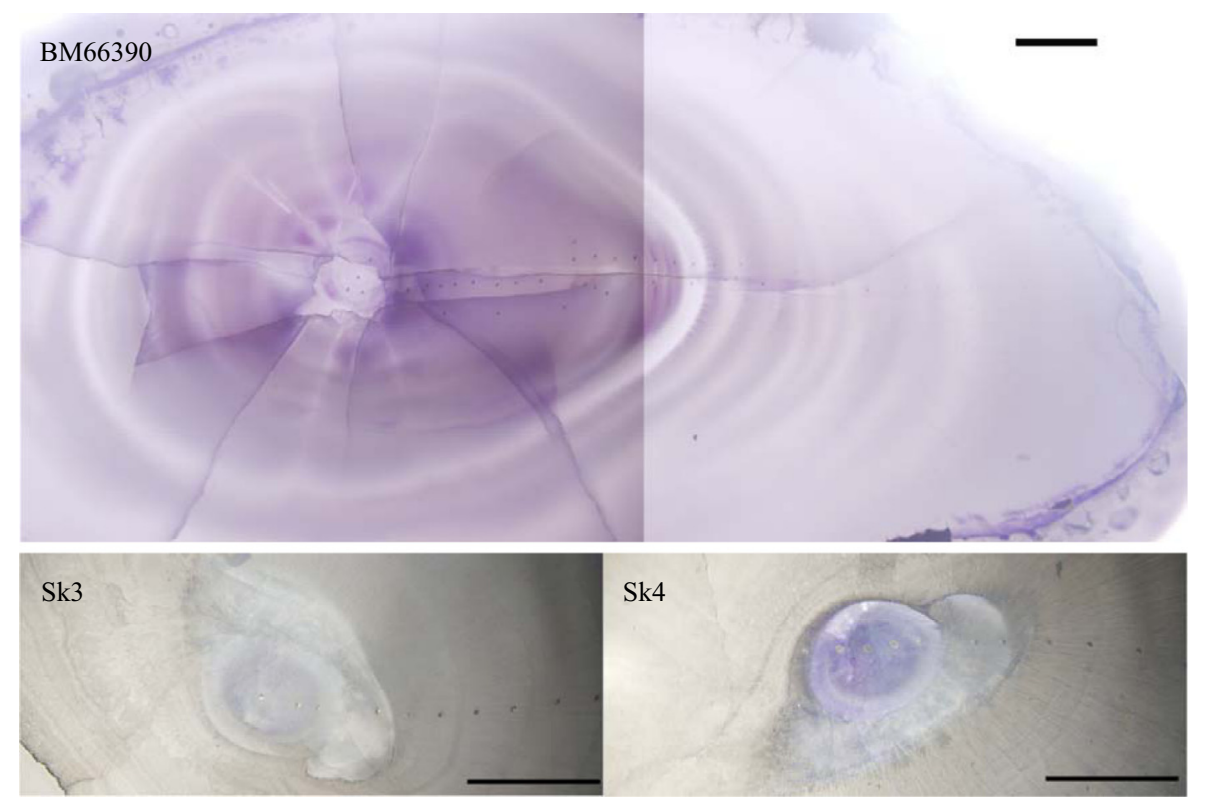

Fig. 8. Toluidine Blue staining indicates protein-rich areas between the otolith core and the otolith check for the blind cusk eel (B. maculatus) (BM66390) and in the larval leptocephalus stage of Kaup's cutthroat eels ( $\mathrm{S}$. kaupii) (Sk3 and SK4). The spots were the locations bombarded by the primary ions while measuring the $\delta^{18} \mathrm{O}_{\text {otolith }}$ values using the SIMS. The image scale bar is $200 \mu \mathrm{m}$. (For interpretation of the references to color in this figure legend, the reader is referred to the web version of this article.)

observed in the carbon-rich areas of the blind cusk eel otolith. According to the CTD profile in Fig. 4, the highest seawater temperature is about $27^{\circ} \mathrm{C}$ in the mixed layer, which may create

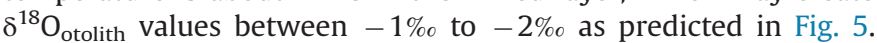
Therefore, these anomaly negative $\delta^{18} \mathrm{O}_{\text {otolith }}$ values down to $-5 \%$ o to $-7 \%$ o should not be interpreted as habitat changes. The larger internal errors were due to gradual secondary ion intensity drifts during data accumulation corresponding to the isotope ratios.

\subsection{Fractionation of $\delta^{18} \mathrm{O}_{\text {otolith }}$ mediated by otolith proteins}

Higher carbon concentrations revealed by X-ray intensity mapping indicated more proteins distributed in these areas of the otoliths (Fig. 7) because the carbon weight percent is much higher in amino acids (30-65\%) than in $\mathrm{CaCO}_{3}(12 \%)$. This inference was supported by the toluidine blue staining (Fig. 8) that revealed the protein-rich area superimposed with carbon-rich areas in the same otoliths. The oxygen isotopic composition of otolith proteins have not yet been measured but Chesson et al. (2011) reported $\delta^{18} \mathrm{O}$ values of fish muscle to be $19.2 \pm 1.3 \%$ (mean $\pm \mathrm{SD}$, VSMOW), which equals $-11.4 \%$ in the VPDB scale. The $\delta^{13} \mathrm{C}$ values of amino acids in otoliths and muscles are very close (McMahon et al., 2011); it is therefore reasonable to assume that the $\delta^{18} \mathrm{O}_{\text {protein }}$ values are consistent either in the otoliths and muscles since both are synthesized from the common pool of amino acids in the blood. The tendency of isotopic fractionation in carbon-rich areas of the otoliths was towards to negative values of $\delta^{18} \mathrm{O}_{\text {protein }}$. Therefore, the lower $\delta^{18} \mathrm{O}_{\text {otolith }}$ values of $-2 \%$ to $-5 \%$ o in the inner part of blind cusk eel otolith (Fig. 2) and $-3 \%$ to $-7 \%$ o near otolith core of Kaup's cutthroat eels (Fig. 3) might result from oxygen emission from the proteins in the otolith. This result indicates that analysis by ion probe should avoid protein-rich areas, where errors may arise due to secondary ion emissions from analyzed area containing variable proportions of carbonates and proteins. However, proteins are not evenly distributed in the otolith but more abundant in the core (Pisam et al., 2002), early life stages and annuli. For example, proteinase $K$ was used to digest otolith proteins that revealed clear daily growth increments in the larval-juvenile stages as well as the annuli and some checks but keep other otolith surfaces intact (Shiao et al., 1999). This phenomenon suggested that otolith proteins are usually rich in the early life stage and become scarcer as the fish grows but may be somewhat concentrated in the annuli or in some otolith checks. Carbon mapping by EPMA or by biological staining are useful for evaluating the heterogeneity of an otolith surface before or after ion probe analysis, as demonstrated in this study.

\subsection{Habitat shift among depths of Kaup's cutthroat eels}

The highly spatially precise lateral resolution of the $\delta^{18} \mathrm{O}_{\text {otolith }}$ analysis clearly revealed aspects of the migratory life history of the deep-sea fishes, which was difficult to resolve by other methods such as the mechanical milling and IRMS (Lin et al., 2012). Kaup's cutthroat eels may have spent a larval stage of around 140-150 days post-hatch in the mixed layer $<200 \mathrm{~m}$ deep and then quickly sank to the deep-sea floor ( $>1000 \mathrm{~m}$ depth) after metamorphosis from the leptocephalus to the glass eel stage, as shown by the increase in $\delta^{18} \mathrm{O}_{\text {otolith }}$ values from negative to positive within the first annulus, indicating the habitat shift from the mixed layer to the seafloor took place within the first year of the eel's life. However, the precise timing of sea floor settlement was unclear because daily growth increments were not discernible after the metamorphosis. The reasons causing the lack of daily rings were still unknown but might be due to the cold water temperature, slower growth rate and permanent darkness in the deep sea. The depth at settlement appeared to be shallower for eel Sk4 than for eel Sk3 but Sk4 migrated slowly towards the deeper bottom and reached the same depth occupied by the eel Sk3.

\subsection{Habitat shift among depths of the blind cusk eel}

The blind cusk eel showed three-stage $\delta^{18} \mathrm{O}_{\text {otolith }}$ profile with negative values from otolith core to one-third of the growth axis, followed by a short and dramatic increase to the plateau that maintained a high level until otolith edge. This result did not support the assumption that the newly-born larvae of the viviparous blind cusk eel living near the sea bottom after birth (Nielsen et al., 1999) but suggested a pelagic larval stage in the mixed layer of the ocean, more than $2000 \mathrm{~m}$ above the benthic habitat of the adult stage where the fish was caught. The duration of each 
ontogenetic stage was still unknown for the blind cusk eel since otolith growth increments and annuli were not discernible. However, a planktonic life stage benefits dispersal of the blind cusk eel and may explain their wide distribution in the Indo-West Pacific Ocean, off the coasts of northern Madagascar, Japan and Australia (Nielsen and Machida, 1985; Paxton et al., 1989).

\subsection{Depth/temperature estimation by $\delta^{18} \mathrm{O}_{\text {otolith }}$ : Feasibility and limitation of SIMS}

The predicted $\delta^{18} \mathrm{O}_{\text {otolith }}$ increases $5 \%$ from 40 to $800 \mathrm{~m}$ depth and becomes almost invariant in deeper layers. This phenomenon implies that precise estimation by $\delta^{18} \mathrm{O}_{\text {otolith }}$ of the depth at which fish reside is feasible between the ocean surface and the thermocline but is problematic at deeper layers ( $>1000 \mathrm{~m}$ ). Nevertheless, $\delta^{18} \mathrm{O}_{\text {otolith }}$ as a proxy of water temperature is still a powerful tool to reveal the habitat shift of fish among ocean surface, thermocline and deep-sea floors. The water temperature was very stable and cold in the deep sea. If the fish consistently live on the seafloor at certain depths, their $\delta^{18} \mathrm{O}_{\text {otolith }}$ would vary little. However, measured $\delta^{18} \mathrm{O}_{\text {otolith }}$ values of the blind cusk eel showed variations up to $1 \%$ during the benthic stage on the seafloor. It is unlikely for the blind cusk eel to experience wide variations of water temperature on the seafloor or to undergo long vertical movements for a blind fish. The variation among measured $\delta^{18} \mathrm{O}_{\text {otolith }}$ values deposited at the same water temperature might be attributed to a matrix effect caused by different textures or compositions on the ground/polished otolith surface. This implies that interpretation of the $\delta^{18} \mathrm{O}_{\text {otolith }}$ profile along the heterogeneous otolith growth axis should consider a potential error of approximately $1 \%$ although the analytical precision of the SIMS was better than $0.56 \%$ (1SD) for repeated measurements on the same otolith increments.

\subsection{Conclusion}

Analysis of $\delta^{18} \mathrm{O}_{\text {otolith }}$ values by SIMS is an effective tool for the retrospective study of fish migration and movement across temperature gradients. This methodology is especially useful because the high lateral resolution of the ion probe permits tracking of temperature and salinity changes over short time frames. The small spot size (approximately $10 \mu \mathrm{m}$ ) used in this study provides more than 10 fold increased of spatial/temporal resolution compared with the mechanical drilling and IRMS (Lin et al., 2012). However, $\delta^{18} \mathrm{O}_{\text {otolith }}$ analysis should avoid sputter at calcified increments that have abundant proteins because organic materials contain oxygen with different oxygen isotopic compositions. Carbon mapping by EPMA or biological staining (e.g., toluidine blue) may increase the accuracy of the technique by allowing researchers to avoid areas where instrument-induced fractionation may occur.

\section{Acknowledgments}

We are grateful to H.-H. Hsieh and Y.-S. Wang for electron microprobe analyses, and E.-Y. Liu for otolith preparation. Brian Jessop, David Cairns and two anonymous reviewers gave useful suggestions to this manuscript. This research was funded by the National Science Council of Taiwan (NSC101-2611-M-002-017 and NSC101-2918-I-002011 to Jen-Chieh Shiao, and NSC101-2116-001-011 to Yoshiyuki lizuka).

\section{References}

Abe, O., Agata, S., Morimoto, M., Abe, M., Yoshimura, K., Hiyama, T., Yoshida, N., 2009. A 6.5-year continuous record of sea surface salinity and seawater isotopic composition at Harbour of Ishigaki Island, southwest Japan. Isot. Environ. Health Stud. 45 (3), 247-258.
Campana, S.E., 1999. Chemistry and composition of fish otoliths: pathways, mechanism and applications. Mar. Ecol. Prog. Ser. 188, 263-297.

Campana, S.E., Neilson, J.D., 1985. Microstructure of fish otoliths. Can. J. Fish. Aquat. Sci. 42, 1014-1032.

Chesson, L.A., Valenzuela, L.O., Bowen, G.J., Cerling, T.E., Ehleringer, J.R., 2011. Consistent predictable patterns in the hydrogen and oxygen stable isotope ratios of animal proteins consumed by modern humans in the USA. Rapid Commun. Mass Spectrom. 25, 3713-3722.

Correia, A.T., Antunes, C., Isidro, E.J., Coimbra, J., 2003. Changes in otolith microstructure and microchemistry during larval development of the European conger eel (Conger conger). Mar. Biol. 142, 777-789.

Cruz, S., Shiao, J.C., Liao, B.K., Huang, C.J., Hwang P.P., 2009. Plasma membrane calcium ATPase required for semicircular canal formation and otolith growth in the zebrafish inner ear. J. Exp. Biol. 212, 639-647.

Degens, E.T., Deuser, W.G., Haedrich, R.L., 1969. Molecular structure and composition of fish otoliths. Mar. Biol. 2, 105-113.

Friedman, I., O'Neil, J.R., 1977. Compilation of stable isotope fractionation factors of geochemical interest. In: Fleisher M, Chap KK (Eds.), Data of geochemistry, sixth ed. U.S. Geol. Surv. Prof. Pap. 440, 1-12.

Goldstein, J.I., Newbury, D.E., Echlin, P., Joy, D.C., Fiori, C., Lifshin, E., 1984. Scanning Electron Microscopy and X-ray Microanalysis-A Text for Biologists, Materials Scientists, and Geologists. Plenum Press, New York.

Hanson, N.N., Wurster, C.M., Todd, C.D., E.I.M.F., 2010. Comparison of secondary ion mass spectrometry and micromilling/continuous flow isotope ratio mass spectrometry techniques used to acquire intra-otolith $\delta^{18} \mathrm{O}$ values of wild Atlantic salmon (Salmo salar). Rapid Commun. Mass Spectrom. 24, 2491-2498.

Høie, H., Andersson, C., Folkvord, A., Karlsen, O., 2004. Precision and accuracy of stable isotope signals in otoluths of pre-reared cod (Gadus morhua) when sampled with a high-resolution micromill. Mar. Biol. 144, 1039-1049.

Hislop, J.R., Gallego, A., Heath, M.R., Kennedy, F.M., Reeves, S.A., Wright, P.J., 2001. A synthesis of the early life history of the anglerfish, Lophius piscatorius (Linnaeus, 1758 ) in northern British water. ICES J. Mar. Sci. 58, 70-86.

Iizuka, Y., 2012. Electron microprobe study of otolith: migratory behavior and habitat of three major temperate species of eels. JEOL News 47 (1), 33-50.

Kim, S.T., O'Neil, J.R., 1997. Equilibrium and nonequilibrium oxygen isotope effects in synthetic carbonates. Geochim. Cosmochim. Acta 61, 3461-3475.

Kolodny, Y., Bar-Matthews, M., Ayalon, A., McKeegan, K.D., 2003. A high spatial resolution $\delta^{18} \mathrm{O}$ profile of a speleothem using an ion-microprobe. Chem. Geol. $197,21-28$.

Lin, Y.J., Iizuka, Y., Tzeng, W.N., 2005. Decreased Sr/Ca ratios in the otoliths of two marine eels, Gymnothorax reticularis and Muraenesox cinereus, during metamorphosis. Mar. Ecol. Prog. Ser. 304, 201-206.

Lin, H.Y., Shiao, J.C., Chen, Y.G., Iizuka, Y., 2012. Ontogenetic vertical migration of grenadiers revealed by otolith microstructures and stable isotopic composition. Deep Sea Res. Part I 61, 123-130.

McMahon, K.W., Fogel, M.L., Johnson, B.J., Houghton, L.A., Thorrold, S.R., 2011. A new method to reconstruct fish diet and movement patterns from $\delta^{13} \mathrm{C}$ values in otolith amino acids. Can. J. Fish. Aquat. Sci. 68, 1330-1340.

Mercer, E.H., 1963. A scheme for section staining in electron microscopy. J. Roy. Microsc. Soc. 81, 179-186.

Minagawa, G., Miller, M.J., Kimura, Y., Watanabe, S., Shinoda, A., Aoyama, J., Tsukamoto, K., 2007. Seasonal differences in catches of leptocephali in the East China Sea and Suruga Bay, Japan. Estuarine Coastal Shelf Sci. 71, 730-740.

Murayama, E., Takagi, Y., Ohira, T., Davis, J.G., Greene, M.I., Nagasawa, H., 2002. Fish otolith contains a unique structural protein, otolin-1. Eur. J. Biochem. 269, 688-696.

Nielsen, J.G., Cohen, D.M., Markle, D.F., Robins, C.R., 1999. FAO Species Catalogue. vol. 18. Ophidiiform Fishes of the World (Order Ophidiiformes). An Annotated and Illustrated Catalogue of Pearlfishes, Cusk-eels, Brotulas and Other Ophidiiform Fishes Known to Date. FAO Fish Synop 125 (18), 178p. Rome: FAO.

Nielsen, J.G., Machida, Y., 1985. Notes on Barathronus maculatus (Aphyonidae) with two records from off Japan. Jap. J. Ichthyol. 32, 1-5.

Northcote, T.G., Hendy, C.H., Nelson, C.S., Boubee, J.A.T., 1992. Tests for migratory history of the New Zealand common smelt (Retropinna retropinna (Richardson)) using otolith isotopic composition. Ecol. Freshwater Fish 1, 61-72.

Okiyama, M., Kato, H., 1997. A pelagic juvenile of Barathronus pacificus (Ophidiiformes: Aphyonidae) from the Southwest Pacific, with notes on its metamorphosis. Ichthyol. Res. 44, 222-226.

Otake, T., Ishii, T., Nakahara, M., Nakamura, R., 1994. Drastic changes in otolith strontium/calcium ratios in leptocephali and glass eels of Japanese eel Anguilla japonica. Mar. Ecol. Prog. Ser. 112, 189-193.

Patterson, W.P., Smith, G.R., Lohmann, K.C., 1993. Continental paleothermometry and seasonality using isotopic composition of aragonite otoliths in freshwater fishes. Geophys. Monogr. 78, 191-202.

Paxton, J.R., Hoese, D.F., Allen, G.R., Hanley, J.E., 1989. Pisces. Petromyzontidae to Carangidae. Zoological Catalogue of Australia, vol. 7. Australian Government Publishing Service, Canberra p. 665.

Pisam, M., Jammet, C., Laurent, D., 2002. First steps of otolith formation of the zebrafish: role of glycogen? Cell Tissue Res. 310, 163-168.

Popper, A.N., Coombs, S.L., 1982. The morphology and evolution of the ear in Actinopterygian fishes. Am. Zool. 22, 311.

Reed, S.J.B., 1993. Electron microprobe analysis. Cambridge University Press, Cambridge.

Riciputi, L.R., Paterson, B.A., Ripperdan, R.L., 1998. Measurement of light stable isotope ratios by SIMS: matrix effects for oxygen, carbon, and sulfur isotopes in minerals. Int. J. Mass Spectrom. 178, 81-112. 
Sasagawa, T., Mugiya, Y., 1996. Biochemical properties of watersoluble otolith proteins and the immunobiochemical detection of the proteins in serum and various tissues in Tilapia Oreochromis niloticus. Fish. Sci 62, 970-976.

Shiao, J.C., Tzeng, C.S., Leu, C.L., Chen, F.C., 1999. Enhancing the contrast and visibility of daily growth increments in fish otoiths etched by proteinase K buffer. J. Fish. Biol. 54, 302-309.

Shiao, J.C., Tzeng, W.N., Collins, A., Iizuka, Y., 2002. Role of marine larval duration and growth rate of glass eels in determining the distribution of Anguilla reinhardtii and $A$. australis on Australian eastern coasts. Mar. Freshwater Res. 53, 687-695.

Shiao, J.C., Wang, S.W., Yokawa, K., Ichinokawa, M., Takeuchi, Y., Chen, Y.G., Shen, C.C., 2010. Natal origin of Pacific bluefin tuna Thunnus orientalis inferred from otolith oxygen isotope composition. Mar. Ecol. Prog. Ser. 420, 207-219.

Söllner, C., Burghammer, M., Busch-Nentwich, E., Berger, J., Schwarz, H., Riekel, C. Nicolson, T., 2003. Control of crystal size and lattice formation by starmaker in otolith biomineralization. Science 302, 282-286.

Tarutani, T., Clayton, R.N., Mayeda, T.K., 1969. The effect of polymorphism and magnesium substitution on oxygen isotope fractionation between calcium carbonate and water. Geochim. Cosmochim. Acta 33, 987-996.

Thorrold, S.R., Campana, S.E., Jones, C.M., Swart, P.K., 1997. Factors determining $\delta^{13} \mathrm{C}$ and $\delta^{18} \mathrm{O}$ fractionation in aragonitic otoliths of marine fish Geochim. Cosmochim. Acta 61, 2909-2919.
Treble, P.C., Chappell, J., Gagan, M.K., McKeegan, K.D., Harrison, T.M., 2005. In situ measurement of seasonal $\delta^{18} \mathrm{O}$ variations and analysis of isotopic trends in a modern speleothem from southwest Australia. Earth Planet. Sci. Lett. 233, $17-32$.

Treble, P.C., Schmitt, A.K., Edwards, R.L., McKeegan, K.D., Harrison, T.M., Grove, M., Cheng, H., Wang, Y.J., 2007. High resolution secondary ionisation mass spectrometry (SIMS) $\delta^{18} \mathrm{O}$ analyses of Hulu Cave speleothem at the time of Heinrich Event 1. Chem. Geol. 238, 197-212.

Trenkel, V.M., Lorance, P., 2011. Estimating Synaphobranchus kaupii densities: contribution of fish behavior to differences between bait experiments and visual strip transects. Deep Sea Res. Part I 58, 63-71.

Weidel, B.C. Ushikubo, T. Carpenter, S.R., Kita, N.T., Cole, JJ. Kitchell, J.F. Pace, M.L. Valley, J.W., 2007. Diary of a bluegill (Lepomis macrochirus): daily $\delta^{13} \mathrm{C}$ and $\delta^{18} \mathrm{O}$ records in otoliths by ion microprobe. Can. J. Fish. Aquat. Sci. 64, 1641-1645.

Wurster, C.M., Patterson, W.P., Cheatham, M.M., 1999. Advances in micromilling techniques: a new apparatus for acquiring high-resolution oxygen and carbon stable isotope values and major/minor elemental ratios from accretionary carbonate. Comput. Geosci. 25, 1159-1166. 